\title{
Performance-Based Competency Requirements for Student Teachers and How to Assess Them
}

\author{
Äli Leijen, Bert Slof, Liina Malva, Pihel Hunt, Jan van Tartwijk, and Marieke van der Schaaf
}

\begin{abstract}
This paper reports a validation study of the performance-based competency requirements model for initial teacher education. An assessment rubric of student teachers' performance-based competency requirements was developed in collaboration between Dutch and Estonian researchers and teacher educators. For the validation of the rubric a Delphi study was carried out. Teacher education experts (five in the Netherlands and 11 in Estonia) were asked to assess and comment on the model. This resulted, per context, in a high degree of consensus and support for the assessment rubric, involving five professional roles, 12 (Estonia) / 11 (The Netherlands) professional activities and five (Estonia) / four (The Netherlands) performance levels for each activity. Furthermore, the experts provide suggestions for assessment forms and required evidence (e.g., lesson plan, lesson observation and test including correction sheets) for the assessment of the professional activities The contribution of this study is an identified and formulated set of roles, professional activities and performance levels that can serve as an assessment rubric for performance-based teacher education. The next step is to implement the rubric and associated assessment forms in an electronic portfolio-system aimed at assessing and guiding student teachers' professional development.
\end{abstract}

Index Terms - Delphi study, workplace-based learning, initial teacher education, entrusted professional activities, rubric assessment.

\section{INTRODUCTION}

The quality of education highly depends on what teachers do (the teaching tasks they perform) and on their competences to adequately fulfil these tasks [1]. For this reason, performance-based educational models have gained considerable attention in teacher education in recent decades (see also [2]). Overall, feedback on and assessment of activities are critical for developing professional expertise and are the most powerful sources for professional learning in the workplace [3], [4], which constitutes a significant part of contemporary teacher education in many countries. However, frequent and personalised feedback that has a lot of potential in this process is used insufficiently and its quality is generally low and often its impact on learning is limited [5]. In this paper we report a study that was conducted in a context of a

Manuscript received October 1, 2015; revised December 22, 2015.

Ä. Leijen, L. Malva, and P. Hunt are with the Institute of Education, University of Tartu, Estonia (e-mail: ali.leijen@ut.ee, liina.malva@ut.ee, pihel.hunt@ut.ee).

B. Slof, J. van Tartwijk, and M. van der Schaaf are with the Social and Behavioural Sciences, University of Utrecht, The Netherlands (e-mail: b.slof@uu.nl,j.vantartwijk@uu.nl,m.f.vanderschaaf@uu.nl).
European project ${ }^{1}$ that aims to improve learning in a workplace by means of personalised and visualised feedback. Prior to moving to the requirements of feedback, we need to establish the most crucial activities student teachers need to develop in their initial teacher training.

Several innovative concepts were utilised in this study to develop a framework to assess and foster the development of student teachers' performance-based competency requirements. Firstly, the concept of core practice that directs teacher educators to identify and organise initial teacher education around the most crucial professional activities a teacher has to carry out [6]-[8]. Core practices are activities that occur with high frequency in teaching practices and student teachers can actually begin to master, allow student teachers to learn more about pupils and about the integrity and complexity of teaching. It means that teaching tasks for teaching practice should be carefully selected in a way that implementation of these tasks supports the best way linking theory with practice and competence in teaching. Secondly, entrusted professional activity (EPA), concept that originates from medical education, also emphasises identification of crucial professional activities in practice, but also points out that these activities need to be practiced under supervision until the student is entrusted to carry them out independently [9], [10]. Thirdly, the idea of rubrics, i.e. descriptions of parts or aspects of work with associated performance level descriptions which might be used for supporting student teachers assessment and feedback [11], [12].

Following the framework an initial assessment rubric of the student teachers' performance-based competency requirements was developed in collaboration between Dutch and Estonian researchers and teacher educators for supervising student teachers' professional development during school internship. The rubric is concurrent with the national teaching standards in The Netherlands and in Estonia and in line with other well-recognised guidelines of teacher education (see for example [13]). According to the initial rubric, student teachers have to fulfil five different professional roles: Designer, supervisor, and evaluator of learning activities; Manager of the work environment; Pedagogue; Member of professional community; and Manager of own professional development. Within each role one or more (depending on the role) professional activities have to be carried out. The professional activities all refer to activities required for teaching profession in primary or

\footnotetext{
${ }^{1}$ This study is part of a larger project WATCHME (Workplace-based e-Assessment Technology for Competency-based Higher Multi-professional Education, http://www.project-watchme.eu/) on the improvement of workplace-based feedback and assessment and professional development by means of learning analytics.
} 
secondary schools (it is expected that the professional activities are applicable to two settings). All professional activities are assessed and evaluated based on their associated performance levels (see example in appendix 2). The performance level descriptions will be used to assess and evaluate at which proficiency level (in the initial version 1=starting, 2=sufficient, 3=good, 4=excellent) a student teacher carried out the professional activities. Based on this information, suggestions for improvement can be provided by the supervisor. For example, if a student teacher is assessed and evaluated at performance level 2 (sufficient), feedback can be provided to guide the student teacher towards level 3 . Based on the performance level descriptions new learning goals and support for how to achieve them can be formulated. Student teachers pass the school internships when they, at least, master all professional activities at the sufficient level. In order to increase the validity of the developed assessment rubric a Delphi study was carried out in the context of Dutch and Estonian teacher education. The Delphi method is an iterative process used to collect and distil the judgments of experts using a series of questionnaires interspersed with feedback [14] allowing a group of individuals, as a whole, to deal with a complex problem avoiding direct confrontation of the experts with one another [15]. The Delphi study was conducted to the answer the following research questions:

1) Are the professional roles and associated professional activities in line with experts' views on what student teachers should master during school internship?

2) Are the proficiency levels for the professional activities in line with experts' views on how well student teacher should carry out the professional activities?

3) What kind of assessment forms is suited for assessing the professional activities during school internship according to experts?

\section{METHOD}

\section{A. Sampling of the Experts' Panel}

The Delphi procedure was carried out at the institutes for teacher education in The Netherlands (Utrecht) and Estonia (Tartu). Experts were selected based on two principles; they (a) will use the assessment rubric for assessing the student teachers, (b) have an applicable specialty, knowledge or relevant experience in this matter. In The Netherlands the panel consisted of four experienced teacher educations (from whom two educators are also a member of the exam committee) and the head of the teacher educator institute. In Estonia the panel consisted of five experienced and acknowledged teachers, who mentor student teachers during their school internship at schools and six teacher educators from the university, who supervise student teachers' school internship from the perspective of university studies. The anonymity and confidentiality was granted for all experts.

\section{B. Steps and Discussion Rounds}

In Step one a first list of professional activities was developed and presented to the four teacher educators and the head of the teacher educator institute in each country. Three discussion and revision rounds were held to develop a final list with professional activities student teachers should master during their internship placement. Three discussion rounds were held to develop a final list with professional activities student teachers should master during their internship placement. In Step two, an assessment rubric containing four performance level descriptions (i.e., beginning, sufficient, good and excellent) and suggested assessment instruments for each activity was composed. By doing so more insight into the natural markers for professional development and how data regarding the development can be obtained. Again, three discussion rounds were held to develop the final assessment rubric and associated assessment instruments (i.e., type of instruments, frequency).

TABLE I: PROFESSIONAL ROLES AND ASSOCIATED PROFESSIONAL ACTIVITIES

\begin{tabular}{ll}
\hline \hline Professional roles & Professional activities \\
\hline & $\begin{array}{l}\text { 1. Sets learning goals for the whole curriculum and } \\
\text { specific lessons. } \\
\text { 2. Designs learning activities (incl. materials and } \\
\text { media) for the set learning goals. }\end{array}$ \\
$\begin{array}{l}\text { Designer, } \\
\text { supervisor and } \\
\text { evaluator of } \\
\text { learning activities }\end{array}$ & $\begin{array}{l}\text { 3. Plans the execution and supervision of learning } \\
\text { activities. } \\
\text { 4. Supervises the execution of learning activities. } \\
\text { 5. Tests to which extend the set learning goals have } \\
\text { been met. }\end{array}$ \\
\hline $\begin{array}{l}\text { Manager of the } \\
\text { work environment }\end{array}$ & $\begin{array}{l}\text { (groups of) students. Directs the communication processes in the } \\
\text { group. }\end{array}$ \\
\hline $\begin{array}{l}\text { Pedagogue } \\
\text { 8. Supervises the development of the student as a } \\
\text { person. }\end{array}$ \\
$\begin{array}{l}\text { Member of the } \\
\text { professional } \\
\text { community } \\
\text { teacher in a broad } \\
\text { context) }\end{array}$ & $\begin{array}{l}\text { 9. Carries out tasks that go beyond the lesson, class } \\
\text { and subject. } \\
\text { 10. Collaborates with colleagues and, if necessary, } \\
\text { parents and other stakeholders. }\end{array}$ \\
\hline \hline
\end{tabular}

\section{Data Collection and Analysis}

The experts were asked to rate the relevance of the rubric's different components: professional roles $\left(1^{\text {st }}\right.$ and $3^{\text {rd }}$ round $)$, professional activities ( $1^{\text {st }}$ and $3^{\text {rd }}$ round) and performance levels $\left(1^{\text {st }}, 2^{\text {nd }}\right.$ and $3^{\text {rd }}$ round). The panel had to rate the relevance of the rubric's components on a 5-point Likert scale and write any comments they found necessary. They were also asked to comment on the (overlapping aspects) formulations. The purpose of the data analysis was to revise the assessment rubric based on the ratings and comments of the experts. After each round the researchers had to decide whether particular role, professional activity or performance level should be accepted, revised or deleted. The decision was based on the stakeholders' ratings of and comments on the relevance of each professional role, activity and performance level $(5=$ very relevant, 1 = not relevant at all). Within each context, three researchers discussed the feedback and suggestions provided by experts and formed decisions for changing the model based on consensus. In order to reach a sufficient agreement between the judgments, a statistical percentage of $75 \%$ was aimed at. 


\section{RESULTS}

\section{A. Step One}

After three rounds it the findings from Step one indicate that, although the experts in two countries slightly differed how to formulate them, five professional roles and 11 associated professional activities are crucial to be mastered during the internship placement (see Table I).

\section{B. Step Two}

After three rounds the findings from Step two indicate that the experts form two countries differed in how many performance level description are required to formatively and summatively assess the student teachers. Whereas four levels seem appropriate for the Dutch context (see Table II), the experts from Estonia preferred to add a fifth performance level description (see Table III). The Estonian experts believed that the Dutch entry level (beginning) might be to high for Estonian student teachers and, therefore, suggested that add a lower entry level for the Estonian context. Another difference was that the Dutch experts preferred to assess the student teachers as specific as possible (i.e., score for each criterion) and the Estonian preferred a more holistic approach (i.e., score for the professional task as a whole).

TABLE II: PERFORMANCE LEVEL DESCRIPTIONS PROFESSIONAL ROLE 1 FOR DUTCH CONTEXT

\begin{tabular}{|c|c|c|c|c|}
\hline Criteria & \multicolumn{4}{|c|}{ Proficiency levels } \\
\hline & Beginning & Sufficient & Good & Excellent \\
\hline $\begin{array}{l}\text { The teacher does/does not } \\
\text { formulate (self-formulated) } \\
\text { learning goals in connection } \\
\text { with specific subject } \\
\text { content. }\end{array}$ & $\begin{array}{l}\text { The teacher takes over the } \\
\text { learning goals of others and } \\
\text { the course book and } \\
\text { occasionally stops to think } \\
\text { about the cohesion between } \\
\text { the set learning goals and the } \\
\text { specific subject content. }\end{array}$ & $\begin{array}{l}\text { The teacher takes over the } \\
\text { learning goals of others and } \\
\text { the course book and often } \\
\text { checks to see whether the set } \\
\text { learning goals match those } \\
\text { of the specific subject } \\
\text { content. }\end{array}$ & $\begin{array}{l}\text { The teacher formulates } \\
\text { his/her own learning goals, } \\
\text { which partially match those } \\
\text { of the specific subject } \\
\text { content. }\end{array}$ & $\begin{array}{l}\text { The teacher formulates } \\
\text { his/her own learning goals, } \\
\text { which match those of the } \\
\text { specific subject content. }\end{array}$ \\
\hline $\begin{array}{l}\text { The teacher does/does not } \\
\text { make use of SMART } \\
\text { (specific, measurable, } \\
\text { acceptable, realistic and } \\
\text { time related) formulated } \\
\text { learning goals }\end{array}$ & $\begin{array}{l}\text { The teacher does not check } \\
\text { if the set learning goals are } \\
\text { SMART formulated. }\end{array}$ & $\begin{array}{l}\text { The teacher regularly checks } \\
\text { if the set learning goals are } \\
\text { SMART formulated. }\end{array}$ & $\begin{array}{l}\text { The teacher formulates } \\
\text { his/her own learning goals } \\
\text { which partially meet } \\
\text { SMART guidelines }\end{array}$ & $\begin{array}{l}\text { The teacher formulates } \\
\text { his/her own learning goals, } \\
\text { which meet SMART } \\
\text { guidelines. }\end{array}$ \\
\hline $\begin{array}{l}\text { The teacher does/does not } \\
\text { take into consideration the } \\
\text { starting situation of students } \\
\text { when formulating learning } \\
\text { goals. }\end{array}$ & $\begin{array}{l}\text { The teacher incidentally } \\
\text { stops to think about the } \\
\text { consistency between the set } \\
\text { learning goals and the } \\
\text { starting situation of the } \\
\text { students. }\end{array}$ & $\begin{array}{l}\text { The teacher regularly checks } \\
\text { if the set learning goals } \\
\text { match with the starting } \\
\text { situation of the students. }\end{array}$ & $\begin{array}{l}\text { The teacher formulates } \\
\text { his/her own learning goals, } \\
\text { which partially match with } \\
\text { the starting situation of the } \\
\text { students. }\end{array}$ & $\begin{array}{l}\text { The teacher formulates } \\
\text { his/her own learning goals, } \\
\text { which match the measured } \\
\text { starting situation of } \\
\text { students. }\end{array}$ \\
\hline
\end{tabular}

TABLE III: PERFORMANCE LEVEL DESCRIPTIONS PROFESSIONAL ROLE 1 FOR THE ESTONIAN CONTEXT

\begin{tabular}{cl}
\hline \hline $\begin{array}{c}\text { Level } 0 \\
\text { (entry) }\end{array}$ & $\begin{array}{l}\text { The teacher has difficulties to find and choose previously developed evaluation instruments and guides. He/she does not interpret the results } \\
\text { and does not give supportive feedback to pupils. }\end{array}$ \\
\hline $\begin{array}{c}\text { Level 1 } \\
\text { (starting) }\end{array}$ & $\begin{array}{l}\text { The teacher chooses previously developed evaluation instruments and guides. He/she interprets the results seldom. He/she rarely gives pupils } \\
\text { a supportive feedback. }\end{array}$ \\
\hline $\begin{array}{c}\text { Level } 2 \\
\text { (sufficient) }\end{array}$ & $\begin{array}{l}\text { The teacher chooses previously developed evaluation instruments and guides. He/she is critical about the instruments and guides, and if } \\
\text { necessary, he/she adapts these. Most of the time the teacher interprets the results and gives pupils a supportive feedback. }\end{array}$ \\
\hline $\begin{array}{c}\text { Level } 3 \\
\text { (good) }\end{array}$ & $\begin{array}{l}\text { The teacher chooses previously developed evaluation instruments and guides. He/she is critical about the instruments and guides, and if } \\
\text { necessary, the teacher adapts and varies these. He/she analyses and interprets the results regularly and gives pupils a supportive feedback. }\end{array}$ \\
\hline $\begin{array}{c}\text { Level } 4 \\
\text { (excellent) }\end{array}$ & $\begin{array}{l}\text { The teacher knows when the new evaluation instruments are necessary and in case of need, he/she develops new relevant instruments and } \\
\text { guides in addition to the available ones. He/she checks the reliability and validity of the instruments. The teacher varies different types of } \\
\text { evaluation, also analyses and interprets the results. He/she gives pupils a supportive feedback and guides them to acquire new studying } \\
\text { strategies. }\end{array}$ \\
\hline \hline
\end{tabular}

TABLE IV: ASSESSMENT FORMS AND REQUIRED EVIDENCE

\begin{tabular}{clll}
\hline \hline Type of evidence & Frequency & Activity & Internship phase \\
\hline Lesson plan & 3 & $1,2 \& 3$ & 1 \\
Lesson series & 2 & $1,2 \& 3$ & 2 \\
Lesson observation form (e.g., Icalt-instrument) & 4 & 4 & 1 (2 assessments) \& $2(2$ assessments) \\
Test (ingl. Correction sheet) & 2 & 5 & $1(1$ assessment 1$) \& 2(1$ assessment) \\
Interpersonal behaviour questionnaire (e.g., QTI instrument) & 4 & 6 & $1(2$ assessments) \& $2(2$ assessments) \\
Transcripts and reports of video-recordings) & 4 & $7 \& 8$ & 1 (2 assessments) \& $2(2$ assessments) \\
Transcripts and reports of meetings & 4 & $9 \& 10$ & $1(2$ assessments $\& 2(2$ assessments) \\
Reflection report & 4 & 11 & $1(2$ assessments) \& $2(2$ assessments) \\
Research plan (incl. lit. review) and research report & 2 & 12 & 1 (1 assessment 1$) \& 2(1$ assessment) \\
\hline \hline
\end{tabular}

The findings from Step two also indicate that experts in two countries agreed to use an assessment form in which the assessors (i.e., institute and internship supervisor) and the student teacher (self-assessment) will be asked to provide a proficiency level score for all criteria/the whole activity. When requesting an assessment student teachers have to submit an assignment (evidence) for the selected professional actives and ask the supervisor to provide a score for the associated indicators. In Table IV the type of assignments and frequency are described per professional activity for the beginning (phase 1) and advanced (phase 2) internship phase. The experts from Estonia preferred to add a $12^{\text {th }}$ professional activity for their context, which relates to conducting research. This activity includes both familiarising oneself with existing 
educational research and conducting research on one's own teaching practices.

\section{CONCLUSIONS}

The aim of this study was to validate the performance-based competency requirements model for the initial teacher education. The research questions were: which professional roles and activities do student teachers need to master during their internship; which performance levels and assessment forms can be used to assess and guide student teachers' professional development? Although in recent decades performance-based educational models have gained considerable attention in teacher education, frequent and personalised feedback is still used insufficiently. For this reason, several innovative concepts (i.e., core practice, entrustable professional activities and rubric assessment) were utilised to develop a new framework to assess and foster the development of student teachers' performance-based competency requirements in the current study. In order to validate the developed model, teacher education experts from two different context participated in three rounds of the Delphi procedure to rate the relevance of the developed assessment rubric and to comment on their ratings.

The validation process resulted, per context, in a high degree of consensus for the assessment rubric, involving five professional roles, 12 (Estonian context) / 11 (Dutch context) professional activities and five (Estonian context) / four (Dutch context) performance levels for each activity. Based on the comments of the experts, the role about designing, supervising and evaluating the learning activities and the associated five professional activities were seen as the most crucial ones since they directly relate to the teaching responsibilities in the classroom. The student teachers are expected to carry out research on teaching and learning in their internship, therefore a new professional activity was added to the assessment rubric for the Estonian context. Further, because the presented performance levels started at a relatively high level for the Estonian context, a new level (the lowest level 0) was introduced.

As a result of the Delphi study it is possible to present a new student teachers' assessment rubric for the teacher education in Estonia and The Netherlands. The professional roles, activities and performance levels can guide and direct the workplace-based learning of the student teachers during their internship. The activities and levels provide the basis for the development of an electronic portfolio system and the application of learning analytics in teacher training. The aim of the latter is to provide easily accessible, dynamic and visual overview of the student teachers' professional development to themselves and their supervisors.

The main limitation of the study was the small number of experts in the panel. Although a small homogeneous group may achieve sufficient results, there is an increase in decision quality as the sample size increases [16]. Secondly, the aim of the study was to revise the assessment rubric based on the ratings and comments of the experts and to reach the consensus of $75 \%$ on the relevance of the components. Since the major revising was done considering the formulation of the components, the suggestion for future research is to ask feedback on whether the rubric can be implemented effectively by both internship and institute supervisors. The next step of the study is to investigate the effects of the implementation of the assessment rubric in an electronic portfolio-system.

\section{ACKNOWLEDGMENT}

This study was conducted within the framework of "Workplace-Based e-Assessment Technology for competency-Based Higher Multi-Professional Education" (WATCHME) project supported by the European Commission 7th Framework Programme (grant agreement No. 619349).

\section{REFERENCES}

[1] M. F. Schaaf and K. M. Stokking, "Construct validation of content standards for teaching," Scandinavian Journal of Educational Research, vol. 55, no. 3, pp. 273-289, 2011.

[2] E. Krull and Ä. Leijen, "Perspectives for defining student teacher performance-based teaching skills indicators to provide formative feedback through learning analytics," Creative Education, vol. 6, no. 10, pp. 914-926, 2015.

[3] K. A. Ericsson, N. Charness, P. J. Feltovich, and R. R. Hoffman, The Cambridge Handbook of Expertise and Expert Performance, New York, USA: Cambridge University Press, 2006

[4] J. Hattie, Visible Learning: A Synthesis of Over 800 Meta-Analysis Relating to Achievement, Routledge: Oxon, 2009.

[5] A. Miller and J. Archer, "Impact of workplace-based assessment on doctors' education and performance: A systematic review," British Medical Journal, vol. 341, 2010.

[6] P. Grossman, K. Hammerness, and M. McDonald, "Redefining teaching, re-imagining teacher education," Teachers and Teaching: Theory and Practice, vol. 15, no. 2, pp. 273-289, 2009.

[7] M. Windschitl, J. Thompson, M. Braaten, and D. Stroupe, "Proposing a core set of instructional practices and tools for teachers of science," Science Education, vol. 96, no. 5, pp. 878-903, 2012.

[8] K. Zeichner, "The turn once again toward practice-based teacher education," Journal of Teacher Education, vol. 63, no. 5, pp. 376-382, 2012.

[9] O. Ten Cate, "Nuts and bolt of entrustable professional activities," Journal of Graduate Medical Education, vol. 5, no. 1, pp. 157-158, 2013.

[10] O. Ten Cate and F. Scheele, "Competency-based postgraduate training: Can we bridge the gap between theory and clinical practice?" Academic Medicine, vol. 82, no. 6, pp. 542-547, 2007.

[11] S. M. Brookhart and F. Chen, "The quality and effectiveness of descriptive rubrics," Educational Review, vol. 3, pp. 343-368, 2015.

[12] A. M. Dekker-Groen, M. F. Van der Schaaf, and K. M. Stokking, "Performance standards for teachers supporting nursing students' reflection skills development," Journal of Nursing Education and Practice, vol. 2, no. 1, pp. 9-19, 2012.

[13] P. Bourgonje and R. Tromp. (2011). Quality Educators: An International Study of Teacher Competences and Standards. Education International/Oxfam Novib. [Online]. Available: http://download.ei-ie.org/Docs/WebDepot/Quality\%20Educators.pdf

[14] H. A. Linstone and M. Turoff, The Delphi Method: Techniques and Applications, pp. 37-71, 2002.

[15] C. Okoli and S. D. Pawlowski, "The Delphi method as a research tool: An example, design considerations and applications," Information \& Management, vol. 42, pp. 15-29, 2003.

[16] G. J. Skulmoski, F. T. Hartman, and J. Krahn, "The Delphi method for graduate research," Journal of Information Technology Education, vol. 6 , pp. 1-21, 2007.

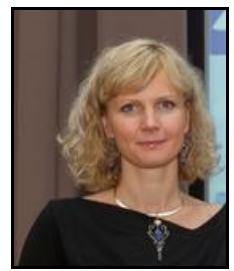

Äli Leijen was born in Tartu, Estonia, in 1979. Her academic background is educational sciences. She is currently a senior research fellow of educational sciences at the Institute of Education of the University of Tartu. She is also the head of the Institute of Education and the coordinator of the doctoral education programme in educational sciences. Her current work is mostly focused on teacher education. 
Her main research themes are supporting students' metacognitive processes in different contexts; development of professional identity; ICT as means for supporting pedagogy and implementing innovations; characteristics influencing successful doctoral education.

Dr. Leijen is a member EARLI, AERA, and ISATT. Since august 2015 she is also a member of the Executive Committee of EARLI.

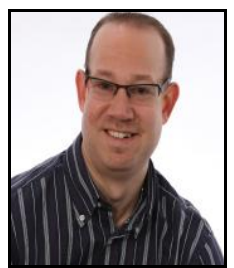

Bert Slof was born in Haarlem, the Netherlands, in 1981. In October 2010 he completed his PhD project, having presented aspects of this study at several national/international conferences.

$\mathrm{He}$ works as an assistant professor in the Department of Social Sciences (Utrecht University). His work focuses on giving lectures and seminars within several educational sciences courses. His research focuses on studying the effects of methods (e.g., feedback and visualizations) fostering collaborative problem solving and the professionalization of (student) teachers. Currently he is involved in the European WatchMe project aimed at fostering student teachers' professional development with digital portfolio's enhanced with learning analytics.



Liina Malva was born in Tallinn, Estonia, in 1989 Her educational background is educational sciences (bachelor's degree of special education from the University of Tartu, Estonia, in 2013; master's degree of educational sciences from the University of Tartu, Estonia, in 2015).

She is currently a junior research fellow of educational sciences at the Institute of Education of the University of Tartu's Faculty of Social Sciences and Education. Her current work is mostly focused on teacher education and the development of professional identity. She is an assistant researcher of a 7th Framework project "Workplace-based e-Assessment Technology for Competency-based Higher Multi-professional Education" (2014-2017).

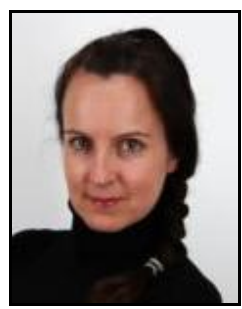

Pihel Hunt was born in Estonia, in 1982. Her educational background is public relations (bachelor's degree in 2006) and educational sciences (master's degree in 2014) from the University of Tartu, Estonia.

She is currently doing her doctorate studies and working as a junior research fellow of educational in the University of Tartu. Her studies and work are mostly focused on teacher education and the development of professional identity. She is a researcher of a 7th Framework project "Workplace-based e-assessment technology for competency-based higher multi-professional education" (2014-2017).

Mrs. Hunt is also a member of international research associations (EARLI, JURE).

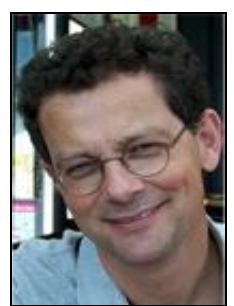

Jan van Tartwijk is a professor in applied educational sciences at Utrecht University and the scientific director of the educational consultancy and training group of Utrecht University's FSBS. This centre provides educational consultancy and applied research for higher, secondary and primary education. Much of his work concerns expertise development of teachers and the use of portfolios in higher-, medical-, and teacher education, but he is also involved in research on teacher-students communication in the classroom and on teacher practical knowledge about teacher-students communication. He presents his work in international journals and is a well-known speaker at educational conferences. He is a reviewer for many international peer-reviewed journals, conferences and grants and supervisor of several $\mathrm{PhD}$ projects.

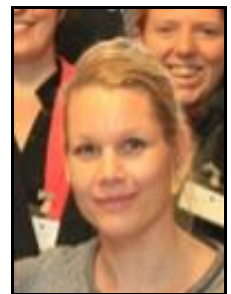

Marieke van der Schaaf was born in the Netherlands, in 1974. Her PhD-study concerned the construct validity of teacher portfolio assessment (2000-2005, cum laude). Besides she led several research projects on educational innovations and performance assessments in secondary education, vocational education, higher education and medical education.

Currently she is an associate professor and director of the master programme Educational Sciences a Utrecht University, the Netherlands. She leads the European FP7 project WatchMe www.project-watchme.eu regarding workplace based assessment with e-portfolios and learning analytics. In particular she studies how assessment can stimulate students' and professionals' expertise.

Dr. Van der Schaaf is a member of EARLI, NVMO and VOR. 